\title{
ENGAGING YOUNG LEARNERS IN LEARNING VOCABULARY: A STUDY ON LEARNERS' PERCEPTION
}

\author{
P-ISSN: 2089-4341 | E-ISSN: 2655-9633 \\ Link: https://uia.e-journal.id/akademika/article/view/805 \\ DOI: $10.34005 / a k a d e m i k a . v 9 i 01.805$ \\ Tryanti R. Abdulrahman \\ tryantia.fkip@uia.ac.id \\ Universitas Islam As-syafi'iyah, Jakarta- \\ Indonesia
}

\begin{abstract}
This study examines students' perception on the implementation of mobile games to engage young learners in learning English vocabulary. Thirty young learners in Islamic elementary school MI As-Syahid, Bekasi were the participant of the study. This qualitative study applied observation, survey, and interview. The findings revealed that: 1) young learners perceived that educational mobile games are effective in improving students' activeness in learning and boost their motivation to learn vocabulary. 2) Young learners expand their vocabulary knowledge through mobile games, and.3) Learners have positive attitudes towards the use of educational mobile games as a supplementary medium of English learning. Additionally, mobile games can also be a potential tool to stimulate the motivation of children who experience failure in learning. This study contributes to the literature regarding vocabulary learning media and the use of mobile game in Indonesia. It highlights young learners' perception of learning using mobile games.
\end{abstract}

Keyword: Mobile games, perception, English, vocabulary, young learner

\begin{abstract}
Abstrak : Penelitian ini menginvestigasi persepsi siswa terhadap implementasi mobile game untuk menarik minat siswa dalam belajar kosakata bahasa inggris. Partisipan dalam penelitian ini adalah 30 siswa MI As-syahid Bekasi . Penelitian ini menggunakan pendekatan qualitative dengan tehnik observasi, survey dan interview dalam pengumpulan data. Hasil penelitian menemukan 1) siswa merasa bahwa mobile games edukatif efektif untuk meningkatkan keaktifan mereka dalam belajar dan meningkatkan motivasi. 2) siswa dapat memperluas pengetahuan kosakata mereka melalui mobile games. 3) siswa memberikan tanggapan positif terhadap penggunaan mobile games edukatif sebagai media pendukung dalam belajar bahasa inggris. Selain itu, mobile games juga dapat dijadikan alat untuk menstimulasi motivasi siswa yang sebelumnya mengalami kegagalan dalam belajar. Penelitian ini memberikan kontribusi literature terkait dengan media pembelajaran kosakata bahasa inggris dan penggunaan mobile game di Indonesia. Penelitian ini menitikberatkan pada pendapat siswa tentang penggunaan mobile game.
\end{abstract}

Keyword: Mobile games, Bahasa Inggris, Persepsi, Kosakata, Siswa EYL 


\section{INTRODUCTION}

Vocabulary plays an important role in language learning. It is the core component of language proficiency and provides much of the basis for how well learners speak, listen, read, and write (T. R. Abdulrahman \& Basalama, 2019; Abrar et al., 2018; Nguyen \& Khuat, 2003; Saldana et al., 2019). According to Cameron (2001) vocabulary knowledge is the knowledge of knowing second language words. A learner not only has the ability to recognize the vocabulary or to connect it with its counterpart but $\mathrm{s} /$ he is also able to use that word in all four language skills. Nation cited in Grimshaw \& Cardoso (2018) mentions three parts of vocabulary knowledge namely knowledge of form, meaning, and use. Meanwhile, Shen (2009) points out two dimensions of vocabulary knowledge, namely vocabulary breadth and depth or quality of vocabulary knowledge. He asserts that vocabulary breadth is "the number of words about the meaning of which a learner has at least some superficial knowledge" ( $p$. 136), and depth of vocabulary knowledge is "a learners" level of knowledge of various aspects of a given word, or how well the learner knows this word" (p. 136). Vocabulary links four skills of language (i.e., speaking, listening, reading, and writing) all together. Many researchers have argued that learning vocabulary and understanding its relationship with language skills allow the learners to master four language skills ( $T$. Abdulrahman, 2018; Abrar et al., 2018; M. A. H. Farrah, 2011; Li \& Cummins, 2019; Nguyen \& Khuat, 2003).Comprehending vocabulary knowledge becomes a challenge for EFL learners. Many opine that gaining knowledge of vocabulary is a complex activity in learning a foreign language; most novice learners are burdened with this activity, and they have low motivation in learning vocabulary (Saeidi \& Mozaheb, 2012). Likewise, (Gardner (2009) viewed that vocabulary is not only defined as word meaning but also includes how vocabulary in a language is structured.Based on experts' reports above, it is clearly seen that vocabulary is essential to be mastered for successful English language use.

Several studies have demonstrated the use of varied approaches, methods, and strategies to seek an appropriate way to teach vocabulary. In Indonesia, as English has been taught in elementary school up to the university level, it is expected that students are able to speak fluently and to communicate effectively in English. However, several reports suggest that students' proficiency in English is still low and unsatisfactory (Sari \& Abdulrahman, 2019; Sundari, 2018). Many young learners find it difficult how to spell and tell the meaning of a specific word, although they have learned English in school. Some are perplexed to understand teachers' explanations in the classroom and cannot answer the teacher's questions. A study by Curenton \& Zucker (2013) has reported that the development 
of vocabulary occurs at its finest in early childhood ages, which allow adults us to intervene the acquisition and development. Young learners deal with unfamiliar words during learning, so language teaching must be delivered in a fun and engaging atmosphere in order to attain a successful class.

In recent years, the utilization of media in teaching and learning processes is needed to engage students and make activities more interesting and effective. The use of media in a class is needed to attract students' attention and to make the classroom activities more interesting and also effective. The use of media in the teaching and learning process is not something new. Many teachers know that media will be helpful.In other words, media is all aids/tools which may be used by the teacher and learners to attain learning objectives.

One of the techniques offering contextual learning of vocabulary is games. Games are a valuable supplement for teaching language skills. Playing games provide students the opportunity to use the language, and the exposure to language skills, and to boost their motivation in learning (Lafta Jassim \& Dzakiria, 2019; Laksmi \& Sudibjo, 2017; Pahmi, 2018; Sung, Chang, \& Liu, 2016). Some benefits of incorporating games in the language class are: 1) helping learners to master the language and promote an engaging learning situation; 2) developing students' motivation and imagination; 3 ) providing the students the opportunity to practice the language; 4 ) accentuating a healthy competition among the students, and; 5) allowing the students to put maximum effort in learning, practicing or reviewing specific language materials (Bakhsh, 2016; Burston, 2013; Gozcu \& Caganaga, 2016; Grimshaw \& Cardoso, 2018; Maulana, R.M, Mujahidah, U \& Abdulrahman, 2018; Sung, Chang, Liu, et al., 2016). In the same notion, the digital educational game is one of the engaging games to be used in the classroom. The use of mobile phones in learning vocabulary has been discussed in many studies. The focus of those studies also ranges from early childhood to adults (Taghizadeh et al., 2017). For instance, Burston (2013) study entitled mobile-assisted language learning: A selected annotated bibliography of implementation studies found that most of a mobile-assisted language learning is now being used by adults for professional academic business and learning a foreign language. A study by Sung, Chang, \& Liu, (2016) highlights the use of mobile games in learning; the results show that the participants are mostly elementary students ( $27 \%)$.

A number of studies on teaching vocabulary using flashcards, both in traditional and digital media (e.g., mobile games), reveal a significant improvement in students' achievement (T. R. Abdulrahman \& Basalama, 2019; Maulana, R.M, Mujahidah, U \& Abdulrahman, 2018; Taghizadeh et al., 2017). Moreover, several scholarly reports confirmed that mobile 
game-based learning becomes one of the successful strategies to help students' vocabulary acquisition (Burston, 2013; Godwin-Jones, 2013; Stockwell, 2010; Wang \& Smith, 2013)

Similarly, Saeidi \& Mozaheb (2012) compare the use of two different strategies in vocabulary learning of Iranian EFL learners: mobile game-based learning and flashcards. This seven-week study was conducted to observe the vocabulary acquisition of $80 \mathrm{EFL}$ learners. Forty students were assigned as the experiment group who participated in a technology-integrated classroom, with a phone-based vocabulary program, SMS communication with the instructor, and internet resources. The remaining 40 students were in a control group, with the printed flashcard treatment. The result signifies that the experiment group has better achievement in the vocabulary learning process compared to the control group. Students also have positive attitudes toward their experience using mobile learning programs or games due to the time and space convenience, quick result of identifying correct answers, and eases of finding different examples while facing problems and mistakes. Another study presented by Ashraf et al. (2014) reports that students who treated by online vocabulary based tests outperformed the control group statistically in the post-test. This indicates that online games are effective in learning English vocabulary for those students.

Burston (2013), in his dissertation, explored the learning process of idiomatic expression and collocation of ESL learners using a mobile application with the total average usage of 7-14 hours. The findings showed that the score of learners depends on the duration of using the program. The participants of this study perceived that idiomobile mobile game provides them the opportunity to learn idiomatic expression and collocation.

The integration of mobile games learning does not only enhance students' achievement and performance but also their motivation. Maulana, R.M, Mujahidah, U \& Abdulrahman, T (2018) analyze the application of mobile games on eight elementary students in learning vocabulary through listening and ask students' responses on its application. The finding shows that mobile games assist them in learning spelling, vocabulary, and listening skills. Students also have positive feedback on the use of mobile games since they felt motivated and interest in learning English through mobile games. A similar study examines students' perspectives on the use of mobile devices in learning English conducted by $\mathrm{Kim}$ et al. (2013).Students perceive the use of mobile devices to create a personalized learning experience outside the classroom. Fifty-three students in three graduate TESOL classes participated in this study. Findings indicate that mobile learning opens up new pedagogical scaffoldings. 
In terms of promoting fluency development in vocabulary, a study by Grimshaw and Cardoso (2018)examines fluency development in a mobile game-activities. The study is driven by a notion of the emphasis of teachers on language use instead of learning new things. This causes students' anxiety as they tend to produce sentences and cause a delay in language development. Their study investigates the use of Spaceteam ESL, a mobile game that requires intelligible and fluent computer-mediated oral exchanges among players. Participants were 20 low-intermediate English as a second language (ESL) students divided into experimental and control groups. The result revealed that the game has a positive influence on students' anxiety. Even though there is no significant difference between the pretest and posttest of both groups, it shows a trend of engagement in games of experiment group outperformed the control group.

Based on the literature above, it is evident that mobile game-based learning (MGBL) has been considered a favorable scheme for successful acquisition and retention of knowledge, and it contributes significantly to the high growth rate of mobile media use. Eventhough media, such as mobile games, provide students something new, but not all teachers know how to implement it correctly. Some might think that the media can disturb the learning process instead of helping students. Crompton (2013) arguesthat using a mobile phone in learning must be very challenging due to the ability of students to operate mobile phones and the duration of using the phone excessively. On the other hand, students who are familiarized with technology devices, particularly young learners, will quickly feel bored with a monotonous way of teaching. Therefore, mobile games, as one of the popular media among children and adults, are utilized for educational purposes. It must be admitted that the use of mobile games has turned into pedagogical use, while some people still consider the negative impact of mobile games rather than its positive impacts. Thus, this study applied a qualitative approach to explore student's perceptions regarding the use of mobile phone games in learning vocabulary. The research questionsin this study are: How does the application of mobile games in classroom vocabulary learning, and what are students' perceptions of mobile games used for vocabulary learning?

\section{METHOD}

\section{Participant}

This research was conducted at Islamic elementary school MI Assyahid. The participant of this research consisted of 27 students in 4th grade in the academic year of 2016/2017, whose age ranged from 10 to 12 years. 


\section{Data analysis}

The data analysis in this study was based on the case study approach of qualitative research that distinguished outcomes of the given situation and case (Creswell and Poth, 2018). The data were collected from questionnaires, interviews, and observation. The questionnaire and interviews were in Indonesian and with English translation to help the participants comprehended the questions. Five questions were analyzed by using a Likert, with scale 1 (Disagree), 2 (Neutral), and 3 (Agree).

The interview was semi-structured, which was more adjustable or flexible for students to answer the questions related to the research topic. It also gave them plenty of time to prepare their answer. The researcher could adjust the questions related to the research topic and was allowed to provide the participants with plenty of time before answering questions. Coding was used to analyze the surveys and interviews; it employed focused and theoretical coding methods (Saldana et al., 2019). The first stage was an overview of the participant's general perception of mobile games in the classroom. Then, the second stage of the coding process was a detailed outcome of students' perception of mobile games relates to their motivation to learn the English language.

\section{Procedures}

Below are the procedures that have been conducted in 45 minutes:

a) The researcher gave an overview of using a laptop to the students.All of the students learned how to use the application like in the preview.

b) After learning the use of the application, the researcher divided the students into groups of three students.

c) English materials were taught based on topic as written in the lesson plan

d) After 30 minutes of learning, the teacher started games as an ice breaking or part of the lesson.

e) The researcher provided every group with a mobile phone and let the group used the phone to play the application under the researcher's monitoring.

f) The application the students accessed during the lesson time were Froggy Phonics, Tic Tac Bananas, and Learn English Vocabulary Words Offline Free.

g) After 12 times of treatment, students were given a questionnaire and being interviewed. 


\section{FINDINGS}

The aim of this study is to analyze the interactions of the students with the vocabulary game and its impact on English vocabulary learning. The following table displays the data of the students' responses. The percentage of students' preference for the statement of, Agree, Neutral, and Disagree.

Table 1. Students' Perceptions on The Use Of Educationalmobile Games.

\begin{tabular}{ll} 
No Statement & \multicolumn{2}{l}{$\begin{array}{l}\text { Agree } \\
\text { (Setuju) } \\
\%\end{array}$} & $\begin{array}{l}\text { Neutral } \\
\text { (Netral) } \\
\%\end{array}$ & $\begin{array}{l}\text { TS } \\
\text { (disagree) } \\
\%\end{array}$ \\
\hline 1. I prefer to learn English vocabulary \\
through games (Saya lebih tertarik belajar \\
kosakata dengan menggunakan media \\
games)
\end{tabular}

From the data displayed on the table 1 above, it is clear that students have positive responses toward the use of mobile games in learning vocabulary. In the first question, the majority of students are eager to learn English vocabulary by mobile games as depicted in the table, $80 \%$ agree, $15 \%$ neutral, and $5 \%$ disagree. The students admit that the feature of mobile games, i.e. Audiovisual and animation, motivates them to learn words and participate in the activity.

The response regarding the second question, as depicted in the table above, is $80 \%$ agree, $18 \%$ neutral, and $2 \%$ disagree with the statement that mobile games help them to understand vocabulary 
easily. This number showed constructive feedback from students in terms of understanding of the material that they have learned through mobile games. Students felt that they have a better understanding of what they have seenon a smartphone.For the third question, the learners confirm that their knowledge has improved due to the integration of mobile games as learning media $(90 \%$ of the students agree with this statement). It is easier for the students to learn through interactive images and wordson a smartphone. Surprisingly, all students did not feel bored to study English through mobile games. This result indicates that mobile games attract students to learning. Furthermore, the majority of students (70\%) felt that they are motivated to study English by using mobile games than other approaches. Students also argue that mobile games are effective in helping them learning vocabulary since it is easy for them to recall vocabulary from the games and memorize them.

\section{DISCUSSION}

The discussion part in this paper will be structured by answering research questions as follow;

1). How does the application of mobile games in classroom vocabulary learning?

Mobile games used in this study are Froggy Phonics, Tic Tac Bananas, and Learn English Vocabulary Words Offline Free. The students played one of these games in each meeting. For example, a total of 27 participants played Learn English Vocabulary Words Offline Free for 30 minutes. Three players played the game in one group, meaning that there were nine groups in total. Based on the observation and interview, most participants had experience in playing games both inside and outside the classroom. Only four participants admit that they had no experience playing games.

From the first to the fourth meeting, the Tic tac Banana game was used in the class. This game uses letter patterns, decoding skills, and word recognition in which the participants combined with the original tic tac toe enjoyment. Students pick and choose amusing monkey pictures, see through a partial word, and they have to complete the words. This game focuses on word recognition, phonics, and decoding, and it has over 100 original pictures and words to choose from. During the treatment, all students were very excited to play this game, and they seemed to enjoy all the content. Students admitted that they like this application because it can be played in a single and a multiplayer mode, featuring pass and play capabilities. With word recognition 
features, decoding, and illustration, this game can improve students' literacy.

The game Learn English Vocabulary Words Offline Free was applied in sixth to tenth meeting with three levels of category: easy, medium, and hard. This application provides English words in which students learn words most easily and effectively. The majority of students enjoy the feature of selecting the subcategories of their interests, such as writing a word, find an image, choose a word, listen and choose, match words, and listen and write. Among those six subcategories, the most favorite category is finding an image, followed by choosing a word, listen and choose, matching words, writing a word, and listen-and-write.

Some students enjoy the game and consider that learning English had never been easier. They opine that learning through pictures (as shown in the game) helped them to comprehend vocabulary because it is easy to associate pictures and words. Considering its features, it goes without saying that this game can help students to achieve common goals in reading as they improve their reading skills, fluency, boost their confidence, and enhance their concentration.

The last game applied in this study for the last two meetings is Froggy Phonics. This is a fun and engaging mobile game that is designed to boost students' literacy skills. The game has phonic patterns complemented with prefix and suffix clues. There are eight different levels and over 800 words for Froggy to discover; only three levels were played by students.

Playing those mobile games puts the students in fun, creative, and relax situations, which leads them to think critically, encourage collaboration, boosting confidence, and develop their self-potential to achieve learning goals. Specifically, the two applications Froggy Phonics and Tic Tac Bananas, allow the students to build their foundation skills, such as word patterns and cognitive skills, including cause and effect.

Overall, those three applications engage students in learning, allow them to collaborate with their friends to challenge them to move forward in the game. The integration of the games also encourage students' social skills like teamwork and develop a sense of community in the classroom. This is because the games are played both individually and in the group. In the classroom setting, mobile games add a variety of learning activities and cheer up the learning situation. Such a notion is in line with the theories about games which designed for learning and have interactive interface designs that contain fun elements (Becker \& Nguyen, 1094; M. Farrah \& Abu-Dawood, 2018; Godwin-Jones, 2011; Naz et al., 2019; Wang \& Smith, 2013) 
2) What are students' perceptions of mobile games used for vocabulary learning?

From the data displayed on the table 1 above, it is clear that students have positive responses toward the use of mobile games in learning vocabulary. In the interview session, right after completing the questionnaire, the students share their thoughts about their experience using mobile games in learning English vocabulary. Two main themes emerged in this study are knowledge gain and motivation.

First, the activities in the game, such as word and picture recognition, coding, listen-and-write, spelling the words and showing movement at the same time enhance students' understanding. Second, the students enjoy the games and eagerly participate in every activity. This situation is in accordance withseveral studies reporting that games help children experiment, discover, and interact with their social environment. Playing games is a fun activity that gives the children the opportunity to practice their English in enjoyable ways(Chalak \& Ahmadi, 2017; Curenton \& Zucker, 2013; OfCom, 2013).

Furthermore, students perceive that mobile games are not only entertaining them but also motivating. This notion is in line with the theory of Prensky (2001) that games have other functions in addition to entertainment purposes. Hence, this study finds that mobile gamescan engage students in the learning activity and develop their knowledge. Such an idea confirms the result seen in Grimshaw and Cardoso's study(2018) that games can improve the logical understanding of the players. Educational games demand the players to finish the problem in the games.

All participants in this study also believe that games are very effective in learning vocabulary. This notion is reflected in their activeness in the class. Such a result echoes the finding seen in a study by Gozcu \& Caganaga (2016) with games the students in the class will be proactive in learning the materials that the teacher gave.

From the interview, the majority of the students love the game, and it stimulates their interest in learning. Seven students clarify that playing games are fun and entertaining because the students do not need to worry about making mistakes during playtime. Two participants admit that mobile games help them to acquire new words by seeing the picture and look at the words. One student commented that "Saya bisa tahu arti beberapa kata dan cerita melalui permainan" (the games somehow helped him to understand some words and contents). Another student mentioned "game- 
nya membantu saya belajar kata bahasa inggris yang baru saya dengar dan saya belajar mengucapkannya" (it helped me to learn new vocabulary in English and how to pronounce the words).

The results of the observation show that there are 27 to 30 students in the class each week. This number indicates students' engagement and interest in learning through mobile games. Moreover, student-centered classroom occurs during the treatment of mobile games because the teacher focuses on students' learning process. For several games focusing on reading skills, the teacher allows the students to use their dictionary while playing games. Such an approach helps them to actively participate in finding the meaning of the word and practice their skill to use dictionary.

Another interesting finding from this study is several students who are previously shy to speak have gained the confidence to speak up. The current study reports a positive correlation between the use of mobile games and English learning motivation as seen in the findings of other scholarly reports (Abrar et al., 2018; M. A. H. Farrah, 2011; Gamlo, 2019; Muslim \& Yasin, 2018; Shabaneh \& Farrah, 2019).

Overall, this study reveals that the integration of mobile games is succesfull to promote elementary students' engagement to learn vocabulary. It can be seen from students' enthusiasm,understanding, interest, motivation, and joyfulness while playing the game. All students are eager to learn new words, get more knowledge about the vocabulary. In addition, mobile games help students to recognize and memorize words as well as pronounce those words properly.

\section{CONCLUSION}

Recently, teaching English as a foreign language requires attractive teaching methods and a variety of media to support learning. The proliferation of technology demands teachers to be creative in using advanced resources, such as mobile phones, to complement the class. Learning activities must be delivered in a fun way, especially for young learners. Thereby, a game-based approach can be an effective way to teach learners. This current study has proven that mobile games can promote young learners' activeness in learning English vocabulary, as well as boost their motivation and interest in the class. Despite the effectiveness of mobile games, teachers need to prioritize learning objectives. Incorporating mobile games in the class prepares the students to keep up with challenges. Additionally, mobile learning can also be a potential tool to motivate those who had failed in learning. 
In conclusion, this study contributes to the literature regarding vocabulary learning media and the use of mobile games for learning in Indonesia. It highlights young learners' perception of learning using mobile games. Moreover, this research offers education practitioners and policymakers valuable insight into EFL education at Indonesian elementary schools and universities. The study recommends methods and media to improve learning outcomes. For future research, studies with longer treatment periods, with an emphasis on gender influence, are worth-investigating.

\section{REFERENCES}

Abdulrahman, T. (2018). The Asian ESP Journal Autumn Edition. The Asian ESP Journal, 14(6), Asian ESP J.

https://www.elejournals.com/asian-esp-journal/asian-esp-journalvolume-14-issue-6-november-2018/\#FullJournalPDF-1

Abdulrahman, T. R., \& Basalama, N. (2019). Promoting Students' Motivation in Learning English Vocabulary through a Collaborative Video Project. Celt: A Journal of Culture, English Language Teaching \& Literature, 19(1), 107. https://doi.org/10.24167/celt.v19i1.493

Abrar, M., Mukminin, A., Habibi, A., Asyrafi, F., Makmur, M., \& Marzulina, L. (2018). "If our English isn't a language, what is it?" Indonesian EFL Student Teachers' Challenges Speaking English. Qualitative Report, 23(1), 129-145.

Ashraf, H., Motlagh, F. G., \& Salami, M. (2014). The Impact of Online Games on Learning English Vocabulary by Iranian (Low-intermediate) EFL Learners. Procedia - Social and Behavioral Sciences, 98, 286291. https://doi.org/10.1016/j.sbspro.2014.03.418

Bakhsh, S. A. (2016). Using Games as a Tool in Teaching Vocabulary to Young Learners. English Language Teaching, 9(7), 120. https://doi.org/10.5539/elt.v9n7p120

Becker, K., \& Nguyen, P. (1094). Review of Technology-enhanced language learning for specialized domains: Practical applications and mobility. Language Learning \& Technology, 21(3), 67-71.

Burston, J. (2013). Mobile-assisted language learning: A selected annotated bibliography of implementation studies 1994-2012. Language, Learning and Technology, 17(3), 157-225.

Chalak, A., \& Ahmadi, B. (2017). Integration of Serious Games in Teaching English as a Foreign Language to Iranian Children. International Journal of Foreign Language Teaching and Research, 5(17), 77-87.

Curenton, S. M., \& Zucker, T. (2013). Instructional Conversations in Early Childhood Classrooms: Policy Suggestions for Curriculum Standards and Professional Development. Creative Education, 04(07), 60-68. https://doi.org/10.4236/ce.2013.47a1009 
Farrah, M. A. H. (2011). Online Communication and Enhancing Language Skills, Motivation, and Cultural Understanding. In AUC TESOL Journal (Issue Special, pp. 128-140).

Farrah, M., \& Abu-Dawood, A. K. (2018). Mohammed A A Farrah 1* , Ala' Khalid Abu-Dawood 1. International Journal of Research in English Education, 3(June), 48-68. https://doi.org/[

Gamlo, N. (2019). The Impact of Mobile Game-Based Language Learning Apps on EFL Learners ' The Impact of Mobile Game-Based Language Learning Apps on EFL Learners 'Motivation. English Language Teaching, 12(April), 49-56. https://doi.org/10.5539/elt.v12n4p49

Gardner, D. (n.d.). Exploring vocabulary: Language in action (H. AristarDry (ed.)).

Godwin-Jones, R. (2011). Emerging technologies: Mobile apps for language learning. Language Learning and Technology, 15(2), 2-11. http://lt.msu.edu/issues/june2011/emerging.pdf

Godwin-Jones, R. (2013). Emerging technologies: integrating intercultural competence into language learning through technology. Language Learning \& Technology, 17(2), 1-11. https://doi.org/10.1002/9781405198431.wbeal0554

Gozcu, E., \& Caganaga, C. K. (2016). The importance of using games in EFL classrooms. Cypriot Journal of Educational Sciences, 11(3), 126. https://doi.org/10.18844/cjes.v11i3.625

Grimshaw, J., \& Cardoso, W. (2018). Activate space rats! Fluency development in a mobile game-assisted environment. Language Learning and Technology, 22(3), 159-175.

Kim, D., Rueckert, D., Kim, D., \& Seo, D. (2013). Students 'Perceptions Erceptions Rception of. Language Learning\& Technology, 17(3), 5273. http://lt.msu.edu/issues/october2013/kimetal.pdf

Lafta Jassim, L., \& Dzakiria, H. (2019). A Literature Review on the Impact of Games on Learning English Vocabulary to Children. International Journal of Language and Literary Studies, 1(1), 47-53. https://doi.org/10.36892/ijlls.v1i1.22

Laksmi, S. W., \& Sudibjo, N. (2017). PENERAPAN SOCIODRAMATIC PLAY UNTUK MENINGKATKAN PENGUASAAN KOSAKATA DAN MOTIVASI BELAJAR SISWA. Akademika Jurnal Teknologi Pendidikan, 7(1), 17-42. https://uia.ejournal.id/akademika/article/view/308

$\mathrm{Li}$, J., \& Cummins, J. (2019). Effect of using texting on vocabulary instruction for English learners. Language Learning and Technology, 23(2), 43-64.

Maulana, R.M, Mujahidah, U \& Abdulrahman, T. (2018). a Case Study of Seven Elementary Students in. LINGUA Jurnal Pendidikan Bahasa, 2(1), 43-51. https://uia.e-journal.id/Lingua/article/view/158

Muslim, \& Yasin, M. F. (2018). Pengaruh Media ICT Dan Kecerdasan Linguistik Terhadap Hasil Belajar Bahasa Inggris (Studi Eksperimen Pada Peserta Diklat Tingkat Menengah Di Pusdiklat Bahasa Badiklat 
Kementrian Pertahanan Jakarta. Akademika Jurnal Teknologi Pendidikan, 7(1), 72-92.

https://doi.org/https://doi.org/10.34005/akademika.v7i01.310

Naz, S., Rasheed, M., \& Rasheed, T. (2019). The Role of Smartphones in Learning English : A Study of Learners ' Perspectives. International Conference on Research in Humanities, 17-28.

Nguyen, T. H. T., \& Khuat, N. T. T. (2003). Learning Vocabulary through Games. Asian EFL Journal, 5(4), 1829-1841. http://www.asian-efljournal.com/dec_03_sub.Vn.php

OfCom. (2013). Children and Parents: Media Use and Attitudes. In Ofcom (Issue October, p. 220).

http://stakeholders.ofcom.org.uk/binaries/research/medialiteracy/october-2013/research07Oct2013.pdf

Pahmi. (2018). Students ' Perceptions of Using Mobile Phones and Smart Phones in Language DEVELOPING CURRICULUM , TEACHER AND. In M. F. Ansyari, A. Hadi, \& M. Syafi'i (Eds.), Students' Perceptions of Using Mobile Phones and Smart Phones in Language Learning (Issue August 2016, pp. 11-30). Kreasi Edukasi Publishing and Consulting Company.

Saeidi, M., \& Mozaheb, M. A. (2012). Comparing vocabulary learning of EFL learners by using two different strategies (mobile learning vs. flashcards). International Journal of Mobile Learning and Organisation, 6(3-4), 303-315. https://doi.org/10.1504/IJMLO.2012.050050

Saldana, J., Ozer, O., Kiliç, F., Alsaif Sarah Ali, M., \& Deris, F. D. (2019). Vocabulary learning through duolingo mobile application: Teacher acceptance, preferred application features and problems. International Journal of Recent Technology and Engineering, 14(2 Special Issue 9), 1-31. https://doi.org/10.35940/ijrte.B1017.0982S919

Sari, M., \& Abdulrahman, T. (2019). DISCOVERY LEARNING (DL) STRATEGY ON STUDENTS READING COMPREHENSION IN REPORT TEXT. LINGUA Jurnal Pendidikan Bahasa, 15(1), 19-26. https://uia.e-journal.id/Lingua/issue/view/42

Shabaneh, Y., \& Farrah, M. (2019). the Effect of Games on Vocabulary Retention. Indonesian Journal of Learning and Instruction, 2(01). https://doi.org/10.25134/ijli.v2i01.1687

Stockwell, G. (2010). Using mobile phones for vocabulary activities: Examining the effect of the platform. Language Learning and Technology, 14(2), 95-110.

Sundari, W. (2018). The Difficulties of Learning English for the Basic English Learners. Journal of Cultural, Literary, and Linguistic Studies, 2(1), 34-41.

Sung, Y. T., Chang, K. E., \& Liu, T. C. (2016). The effects of integrating mobile devices with teaching and learning on students' learning performance: A meta-analysis and research synthesis. Computers and Education, 94, 252-275. 
https://doi.org/10.1016/j.compedu.2015.11.008

Sung, Y. T., Chang, K. E., Liu, T. C., Chang, C. Y., \& Hwang, G. J. (2016). Trends in digital game-based learning in the mobile era: a systematic review of journal publications from 2007 to 2016. International Journal of Mobile Learning and Organisation, 94(1), 68. https://doi.org/10.1504/ijmlo.2019.10016603

Taghizadeh, M., Vaezi, S., \& Ravan, M. (2017). Digital Games, Songs and Flashcards and their Effects on Vocabulary Knowledge of Iranian Preschoolers. International Journal of English Language \& Translation Studies, 5(4), 156-171.

Wang, S., \& Smith, S. (2013). Reading_and_grammar_learning_t.PDF. Language Learning \& Technology, 17(3), 117-134. 